EMBRYARIDDLE
Aeronautical University

SCHOLARLY COMMONS
International Journal of Aviation, Aeronautics, and Aerospace

\title{
Brand Awareness, Purchase Intention and Price Premium of International Airlines Operating between Australia and the United Kingdom
}

Yi Gao

Purdue University, yigao@purdue.edu

Nigel Wai Keong Choy

Swinburne University of Technology, 100974260@student.swin.edu.au

Follow this and additional works at: https://commons.erau.edu/ijaaa

Part of the Management and Operations Commons, and the Tourism and Travel Commons

\section{Scholarly Commons Citation}

Gao, Y., \& Choy, N. W. (2019). Brand Awareness, Purchase Intention and Price Premium of International Airlines Operating between Australia and the United Kingdom. International Journal of Aviation, Aeronautics, and Aerospace, 6(3). https://doi.org/10.15394/ijaaa.2019.1345

This Article is brought to you for free and open access by the Journals at Scholarly Commons. It has been accepted for inclusion in International Journal of Aviation, Aeronautics, and Aerospace by an authorized administrator of Scholarly Commons. For more information, please contact commons@erau.edu. 


\section{Introduction}

Air transportation is a competitive industry, both domestically and internationally. With the deregulation of the airline industry in major domestic markets such as the United States and Australia (Airline Deregulation Act, 1978; Bureau of Transport Economics, 1995) and the wide adoption of open skies agreements (U.S. Department of State, n.d.) on international markets, it has become increasingly rare to spot a busy route that is serviced by a single carrier. Airlines are flocking to profitable routes, trying tirelessly to differentiate themselves from competitors, and brawling for higher market shares.

The competition among airlines offers travelers with more choices. While the fundamental product provided by airlines in essence is similar to each other, which is to carry passengers and cargo from origins to destinations, flights operated by different carriers do differentiate from each other in terms of departure/arrival times, number of stops, aircraft types, etc. There have been a plethora of studies addressing factors that could influence passengers' choice of airlines (Brey \& Walker, 2011; Gao \& Koo, 2014; Moreno, 2006; Yai, Takada, \& Okamoto, 1997). Among these factors, airfare plays a critical role in travelers' decision making, especially to budget-sensitive leisure travelers.

As most other consumer goods or services, flights offered by airlines are priced differently and dynamically. Due to the wide application of Global Distribution System (GDS), airlines' pricing is entirely transparent to each other. An airline could almost respond simultaneously to any price adjustment made by competitors. However, airlines are still charging distinctive airfares on the same route for the same departure and arrival date. This suggests that the pricing power of airlines is obviously not identical.

At the time of booking, tangible differences in flights are presented to travelers, such as departure/arrival times, number of connections, aircraft type and cabin classes. These visible advantages or disadvantages are already priced in displayed airfares. Less preferred flights such as red-eye flights or indirect flights are usually more competitively priced in order to compensate for inconveniences. Pricing of flights is also determined by subjective and intangible factors such as travelers' preferences and perceptions of the airlines' overall brand reputation. Such preferences and perceptions could be from previous experience with the airline, or stem from brand equity of airlines.

Brands are an essential element of modern life, and have a strong impact on how products and services are being perceived and valued. "The perceived added value that a brand gives to a product, when compared to the same unbranded product" is defined as brand equity (Macias \& Rodriquez, 2018, p.2). Brand equity has multiple dimensions. In one of his most cited works, Aaker (1996) provided a framework of 10 dimensions in evaluating and tracking brand 
equity, which are price premium, satisfaction/loyalty, perceived quality, leadership, perceived value, brand personality, organizational associations, brand awareness, market share and price, and distribution indices.

Another frequently mentioned concept is brand strength, which is how consumers perceive and behave towards a brand in the marketplace (Anselmsson, Vestman Bondesson, \& Johansson, 2014; Persson, 2010). Brand strength is regarded by many as a component of brand equity, along with brand image and brand value (Keller \& Lehmann, 2003; Persson, 2010). Brand strength itself is composed of two dimensions, which are brand loyalty and price premium. Price premium means the amount a customer will pay for the brand in comparison with another brand offering similar benefits (Aaker, 1996). Price premiums are widely viewed as the most useful dimension in measuring brand equity (Aaker, 1996; Blackston, 1995; Sethuraman, 2001).

Quite a number of studies have been conducted in different domains to analyze the influence of brand equity on price premium. In the Swedish grocery retail industry, Anselmsson et al. (2014) found that in addition to traditional brand equity dimensions, uniqueness is also a dimension of brand equity and thus drives price premium for grocery products of different brands. This supports their earlier findings on brand equity model (Anselmsson, Johansson, \& Persson, 2007). In Japan, Masuda and Kushiro (2018) found that among the four conventional brand equity dimensions, which are awareness, loyalty, perceived quality, and brand associations, loyalty has the most significant effect on consumers' willingness to pay price premium for private labels in fresh produce. In Spain, researchers have studied a very specific product, olive oil (Gómez, Martín-Consuegra, Díaz, \& Molina, 2018). The determinants they examine are awareness, corporate social responsibility, origin, quality and positioning. This is different from conventional brand equity models, such as Aaker's (1996). Their study finds that positioning is the strongest and unique determinant of price premium, and four other determinants will only drive brand loyalty but not price premium. Through a specially designed experiment, Suchomelova, Prochazka, and Durinik (2017) identify that personal interest will drive consumers to pay price premium for products that they feel emotionally attached. In this specific case, it is shopping bags, mugs, and tank tops bearing visual references to consumers' local culture.

There has been quite an effort trying to find a brand equity model that fits the airline industry. Sarker, Mohd-Any, and Kamarulzaman (2019) conduct a systematic and critical review of consumer-based brand equity literature. They narrowed down from initially 1.8 million search results to finally four highly cited models. Considering the nature of airlines being a service industry, they recommend the service branding model proposed by Berry (2000). In this model, Berry clarifies the difference between brand meaning and brand awareness. Brand meaning is the customers' dominant perceptions of the brand, or the immediate 
impression when the brand is mentioned. And brand awareness is whether the customers have heard of the brand or not (Berry, 2000). Both brand meaning and brand awareness are contributing to brand equity, though at different extents. Berry (2000) suggests that brand meaning is only affected by direct service, but brand awareness can be affected by the indirect experience (communications) as well as company's presented brand.

Researchers are trying to develop a more airline-specific brand equity model. Chen and Tseng (2010) propose that brand awareness, brand image, perceived quality and brand loyalty would constitute a customer-based airline brand equity model. They suggest brand loyalty is the primary determinant of brand equity among these four dimensions. This model is a subset of Aaker (1996). Three out of the four dimensions are from Aaker's original brand equity ten, with the only difference being brand image. But even this dimension could be represented by brand value and brand personality from Aaker (1996). Another customer-based airline brand equity model also has four dimensions: airline flight service quality, airline brand affect, airline brand awareness, and airline brand association (Thakshak, 2018). Except for airline brand affect, three other dimensions are also from Aaker's (1996) brand equity ten. Brand effect here refers to the emotional feeling and attitude toward brand, which in essence is similar to Aaker's customer satisfaction dimension. Therefore, no completely new dimension has actually been developed for the airline industry from either study.

There are also applied brand studies in air transportation. For instance, Chen and Chang (2008) analyzed the relationship between brand equity, brand preference, and customers' purchase intentions on international air passengers' decision in Taiwan using simultaneous maximum-likelihood-estimation. Their study found that brand equity had a positive effect on both brand preference and purchase intentions for the high switching cost group. However, for the low switching cost group, the effect of brand equity on purchase intentions is not significant. Another study by Jeng (2016) does not use any of the abovementioned brand equity model. Instead, it is about the relationship between brand credibility and consumer purchase intention, which is found to be positive. Brand credibility would increase consumers' decision convenience and enhance affective commitment.

Motivated by the aforementioned studies, especially ones in the air transportation sector, and intrigued by how people perceive airlines brands, this study aims to investigate the effect of brand awareness on purchase intention and price premium on a specific route: Australia - the United Kingdom. A specific route is used in order to enhance the relatedness of participants to survey questions, and the UK is selected due to the close economic, ethnic and historical tie between the two nations. Research questions to be addressed by this study include: 
- How familiar are people living in the metropolitan Melbourne area with international airlines operating between Melbourne the United Kingdom?

- What effect does brand awareness have on passengers' purchase intention and price premium of airfares when travelling internationally?

\section{Method}

To collect travelers' perceptions and preferences of airline brands, this study used the method of survey. Surveys are known to be able to collect responses from samples of decent size efficiently and effectively. Subjectivity of researchers could be controlled in the process of data collection. The instrument used by the survey for data collection is constructed and administered by researchers of this study. The collection of responses from survey participants has been approved by the ethics committee of the university with which researchers are affiliated to ensure the rights of participants are properly protected.

There are multiple factors that could affect travelers' choice of flights when making reservations for trips (Gao \& Koo, 2014). This study eliminated factors that were not directly related to the research questions in constructing a basic international trip scenario. Without listing marketed airfare, departure/arrival times, or connections, the study only presented participants a simplified round trip from Melbourne to London. Survey participants were asked about their familiarity and preferences with regards to airlines that are currently operating between Australia and the United Kingdom.

The survey questionnaire was composed of six questions, to directly address the key issues and, at the same time, to remove the barrier of participation. In the first three questions, participants are asked to provide basic background information, including age group they belong to, income bracket, and their travel frequencies in the last 12 months. By collecting such data, it was anticipated that statistical analysis could be conducted later to compare responses from participants of different sub-groups.

Question 4 checked how familiar participants were with airlines that operate between Australia and the UK, with or without connections. Participants were presented with 16 different airline logos and are asked by researchers in person to name all the airlines they recognize. It was expected that false claims of recognition could be reduced to minimum through this approach.

Question 5 asked participants to list up to three airlines that they would be more likely to fly. Participants were provided with a reference airfare (A\$2,000), to be used to help make the decision if they are willing to pay that amount or more to fly with the chosen airlines. This question intended to measure passengers' purchase intention with different airlines.

In Question 6, survey participants were asked to group airlines into two categories, using "+" or "-“" marks. If the participant related a particular airline to 
the premium brand category, then the airline would be marked as "+". By contrast, if an airline was perceived to be more of a discount brand, then the participant put it into the "_." group. Participants were only asked to group airlines that they had a strong opinion about instead of being required to mark all the airlines. By doing so, this study collected a more accurate impression of participants.

In addition to the descriptive analysis which are used to investigate brand awareness, purchase intention, and price premium of survey participants with airlines operating between Australia and the UK, this study also conducted a series of statistical analysis to examine the correlation among these factors, separately for each airline. Due to the design of the survey instrument, responses to Q4-Q6 are categorical in nature. Therefore, Chi-Square test of association was used here. Assumptions for Chi-square test of association are examined before these tests are conducted (McHugh, 2013). As suggested, Cramer's V was calculated to measure the strength of correlation.

The three null hypotheses used in Chi-square tests are:

$\boldsymbol{H}_{01}$ : There is no association between brand awareness and purchase intention for airlines being investigated in this study.

$\boldsymbol{H}_{02}$ : There is no association between brand awareness and price premium for airlines being investigated in this study.

$\boldsymbol{H}_{03}$ : There is no association between purchase intention and purchase intention for airlines being investigated in this study.

IATA 2-letter codes are used to denote airlines in the results section. See Table 1 for the mapping between airlines and IATA codes.

Table 1

IATA codes for airlines

\begin{tabular}{clcl}
\hline IATA & \multicolumn{1}{c}{ Airline } & IATA Code & \multicolumn{1}{c}{ Airline } \\
Code & Air India & GA & Garuda Indonesia \\
AI & British Airways & KE & Korean Air \\
BA & Cathay Pacific Airways & MH & Malaysia Airlines \\
CX & China Eastern Airline & QF & Qantas Airways \\
MU & China Southern Airline & QR & Qatar Airways \\
CZ & Emirates & BI & Royal Brunei Airlines \\
EK & Etihad Airways & SQ & Singapore Airlines \\
EY & EVA Air & TG & Thai Airways \\
BR & & &
\end{tabular}




\section{Results}

Data collection of this study occurred near the Glenferrie Train Station of Melbourne, Australia. A research team collected responses from participants using face-to-face approach. Convenience sampling was adopted by this project out of practical considerations. The research team had approached a total number of 500 passers-by in a 4-week period during September - October 2017. Potential participants were briefed with the purpose of the project and were presented with the consent statement before they decided to participate. A total number of 259 valid responses were collected, representing a response rate of 51.8\%.

As of the demographic information, survey participants were mostly candid about their age and travel frequency in the previous year, but were reluctant to disclose income. More than half of the participants chose "not to disclose" even they were only asked to indicate the range of income. As the data was collected in a public space near a major university, approximately $40 \%$ of the participants were 25 years old or younger, and close to $70 \%$ of the participants were 35 years or younger at the time of data collection. See Table 2 for the summary of demographic data.

Table 2

Summary of Demographics

\begin{tabular}{llrr}
\hline Variable & Level & Count & Percentage \\
\hline Age & $18-25$ & 105 & $40.54 \%$ \\
& $26-35$ & 74 & $28.57 \%$ \\
& $36-45$ & 42 & $16.22 \%$ \\
& $46-59$ & 28 & $10.81 \%$ \\
& $60+$ & 4 & $1.54 \%$ \\
& Prefer not to say & 6 & $2.32 \%$ \\
\hline Income & $\$ 0-\$ 18,200$ & 36 & $13.90 \%$ \\
& $\$ 18,201-\$ 37,000$ & 32 & $12.36 \%$ \\
& $\$ 37,001-\$ 87,000$ & 32 & $12.36 \%$ \\
& $\$ 87,000-\$ 180,000$ & 5 & $1.93 \%$ \\
& $\$ 180,001+$ & 4 & $1.54 \%$ \\
& Prefer not to say & 150 & $57.92 \%$ \\
\hline Trips & 0 & 70 & $27.03 \%$ \\
& $1-5$ & 165 & $63.71 \%$ \\
& $6-10$ & 18 & $6.95 \%$ \\
& $11-20$ & 1 & $0.39 \%$ \\
& $20+$ & 1 & $0.39 \%$ \\
\hline
\end{tabular}


In terms of brand awareness, as expected for an Australia-based sample, the most recognized airline logo is Qantas. Seventy-four-point one percent (74.1\%) of the participants successfully named the Kangaroo symbol among all the logos. Singapore Airlines, Thai Airways, Emirates, and Malaysia Airlines are also more recognizable than other airlines. The least recognized brands are Garuda Indonesia (7.7\%), China Eastern (7.7\%), and Korean Air (8.1\%). See Figure 1 for brand awareness standings.

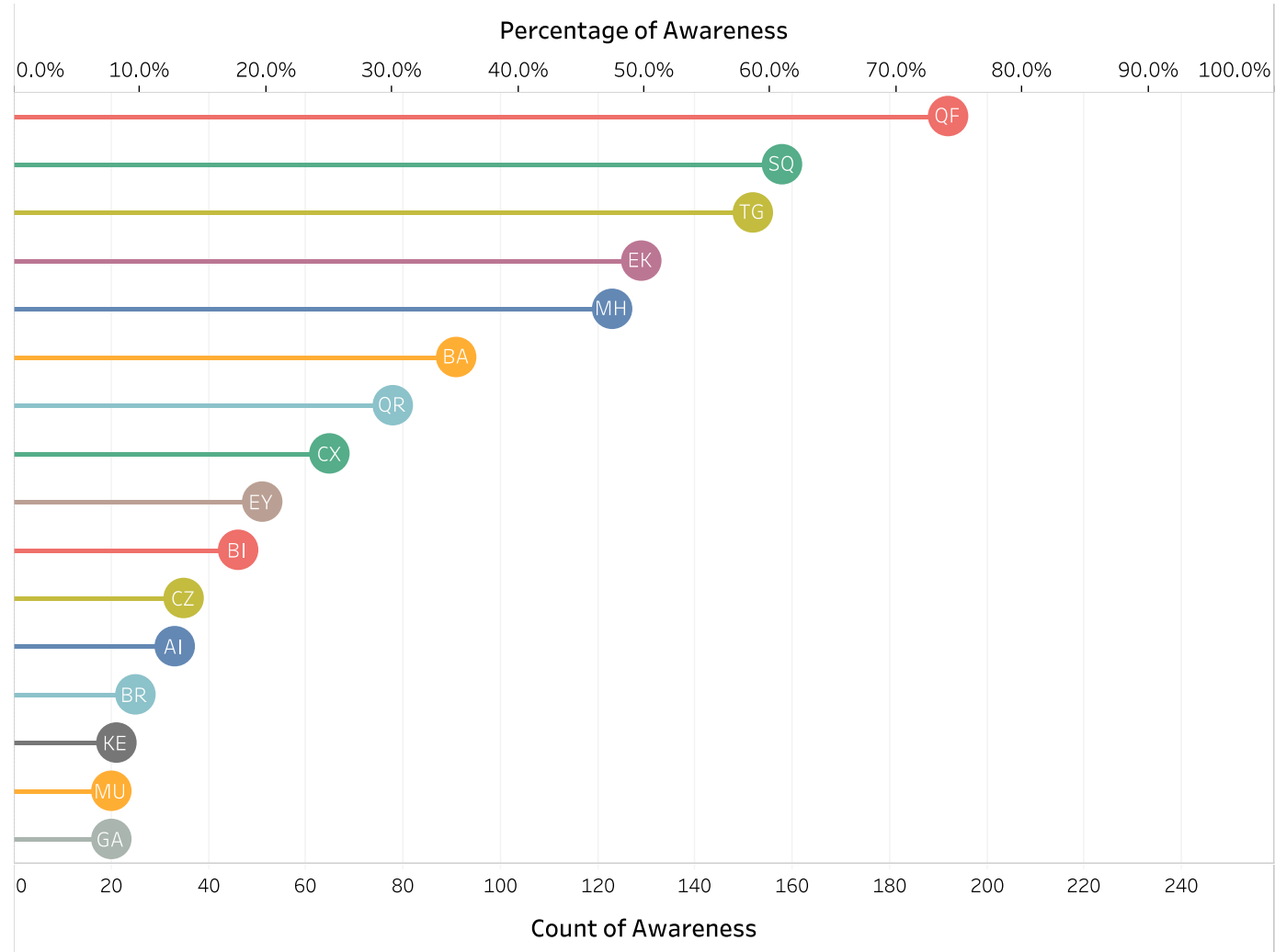

Figure 1. Airline brand awareness by numbers and by percentages.

In terms of the purchase intention and airline preference, 115 out of 259 survey participants picked Qantas over other airlines when flying to the UK, putting the flag carrier of Australia as the most preferred airline. This is followed by Singapore Airlines (96), and Emirates (92). Airlines that received less than 10 votes in this question are Garuda Indonesia (1), China Eastern Airlines (2), Air India (3), Korean Air (5), Royal Brunei Airlines (6), and China Southern Airlines (7). See Figure 2 for standings of airline purchase intention. 


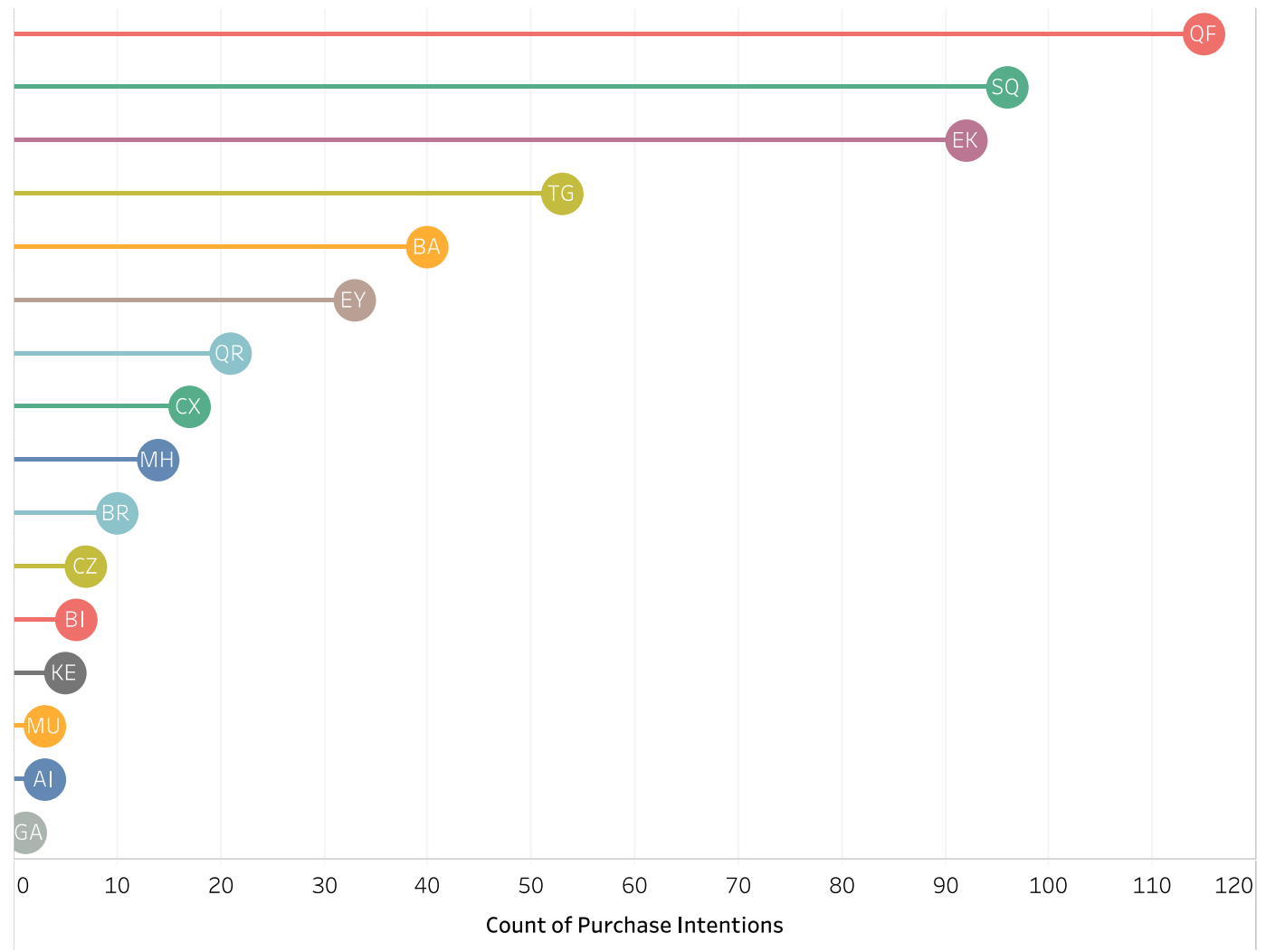

Figure 2. Preferred airlines for travelling between AU \& UK.

Question 6 intended to capture the relationship between brand awareness and price premium (or discount). Qantas and Emirates received the most favorable votes as the premium airline choice while receiving only a small number of votes as discount brands. Thai Airways, thought as one of the most recognizable brands among survey participants, was considered by 75 participants as a discount choice when flying to the UK. Another interesting finding is Singapore Airlines. When other airlines were viewed either as premium or discount choices in a convincing way, Singapore Airlines received 66 premium votes and 49 discount votes, displaying a dichotomous choice among participants. See Figure 3 for details of response to this question. 


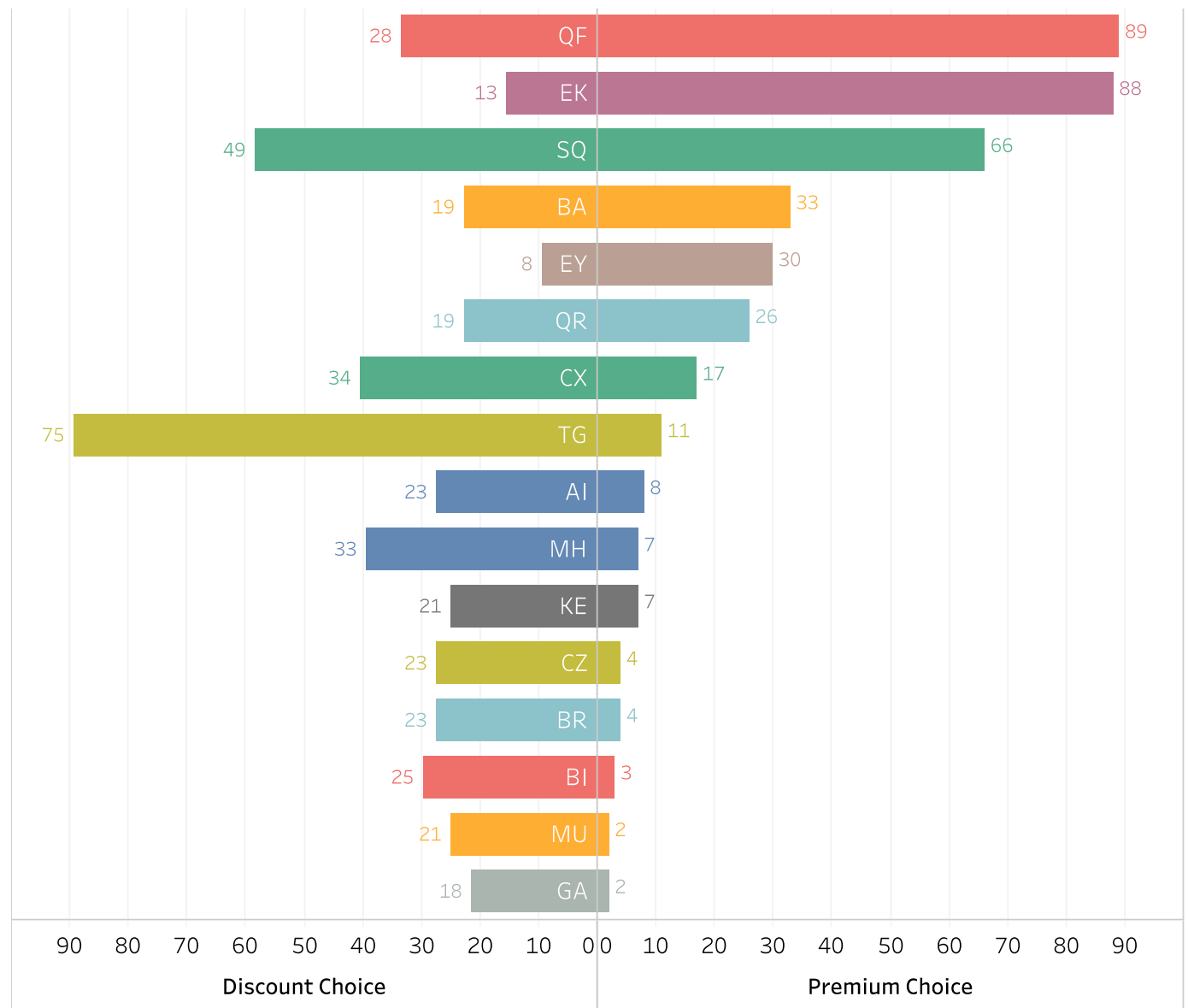

Figure 3. Premium choice vs. discount choice.

Assumptions necessary for Chi-square tests are examined according to McHugh (2013). The first five assumptions with regard to the nature of measures themselves can be easily met. The focus of the assumption check is on the very last one: The value of the cell Expected Count should be 5 or more in at least $80 \%$ of the cells, and no cell should have an expected of less than one. Results of the assumption check are summarized in Table 3 . The primary cause for airlines failing to meet the assumption requires is due to the low number of votes received for those airlines. When these assumptions are met, the validity of Chi-square tests can be guaranteed. 
Table 3

Assumption Check Results for Chi-Square Tests

\begin{tabular}{|c|c|c|c|}
\hline Airline & $\begin{array}{l}\text { Brand Awareness } \\
\text { \& } \\
\text { Purchase Intention }\end{array}$ & $\begin{array}{l}\text { Brand Awareness \& } \\
\text { Price Premium }\end{array}$ & $\begin{array}{c}\text { Purchase Intention } \\
\text { \& Price Premium }\end{array}$ \\
\hline AI & $\mathrm{x}$ & $\mathrm{x}$ & $\mathrm{x}$ \\
\hline BA & $\sqrt{ }$ & $\sqrt{ }$ & $\sqrt{ }$ \\
\hline $\mathrm{CX}$ & $\sqrt{ }$ & $\sqrt{ }$ & $\mathrm{x}$ \\
\hline MU & $\mathrm{x}$ & $\mathrm{x}$ & $\mathrm{x}$ \\
\hline $\mathrm{CZ}$ & $\mathrm{x}$ & $\mathrm{x}$ & $\mathrm{x}$ \\
\hline EK & $\sqrt{ }$ & $\sqrt{ }$ & $\sqrt{ }$ \\
\hline EY & $\sqrt{ }$ & $\sqrt{ }$ & $\mathrm{x}$ \\
\hline $\mathrm{BR}$ & X & $\mathrm{x}$ & $\mathrm{x}$ \\
\hline GA & $\mathrm{x}$ & $\mathrm{x}$ & $\mathrm{x}$ \\
\hline $\mathrm{KE}$ & $\mathrm{x}$ & $\mathrm{x}$ & $\mathrm{x}$ \\
\hline $\mathrm{MH}$ & $\sqrt{ }$ & $\mathrm{x}$ & $\mathrm{x}$ \\
\hline QF & $\sqrt{ }$ & $\sqrt{ }$ & $\sqrt{ }$ \\
\hline QR & $\sqrt{ }$ & $\sqrt{ }$ & $\mathrm{x}$ \\
\hline $\mathrm{BI}$ & $\mathrm{x}$ & $\mathrm{x}$ & $\mathrm{x}$ \\
\hline SQ & $\sqrt{ }$ & $\sqrt{ }$ & $\sqrt{ }$ \\
\hline TG & $\sqrt{ }$ & $\sqrt{ }$ & $\sqrt{ }$ \\
\hline
\end{tabular}

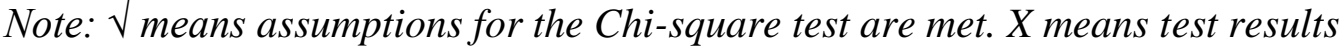
do not satisfy Chi-square assumptions. These cells are also greyed out.

Chi-square tests are conducted for airlines that meet the assumption requirements, using responses collected from the survey. For instance, participants' response to Qantas in this study can be summarized in Table 4 - 6.

Table 4

Count of Responses to Brand Awareness and Purchase Intention for Qantas

\begin{tabular}{cccc}
\hline \multirow{2}{*}{ Qantas } & \multicolumn{2}{c}{ Purchase Intention } \\
\cline { 2 - 4 } & & Yes (1) & No (0) \\
\hline Brand & Yes (1) & 113 & 79 \\
Awareness & No (0) & 2 & 65 \\
\hline
\end{tabular}


Table 5

Count of Responses to Brand Awareness and Price Premium for Qantas

\begin{tabular}{ccccc}
\hline \multirow{2}{*}{ Qantas } & & \multicolumn{3}{c}{ Price Premium } \\
\cline { 3 - 5 } & & $\begin{array}{c}\text { Discount Group } \\
(-1)\end{array}$ & $\begin{array}{c}\text { No Response } \\
(0)\end{array}$ & $\begin{array}{c}\text { Premium Group } \\
(1)\end{array}$ \\
\hline \multirow{3}{*}{ Brand } & $\begin{array}{c}\text { Yes } \\
(1)\end{array}$ & 27 & 79 & 86 \\
Awareness & $\begin{array}{c}\text { No } \\
(0)\end{array}$ & 1 & 63 & 3 \\
\hline
\end{tabular}

Table 6

Count of Response to Purchase Intention and Price Premium for Qantas

\begin{tabular}{lcccc}
\hline \multirow{2}{*}{ Qantas } & & \multicolumn{3}{c}{ Price Premium } \\
\cline { 3 - 5 } & & $\begin{array}{c}\text { Discount Group } \\
(-1)\end{array}$ & $\begin{array}{c}\text { No Response } \\
(0)\end{array}$ & $\begin{array}{c}\text { Premium Group } \\
(1)\end{array}$ \\
\hline \multirow{2}{*}{$\begin{array}{c}\text { Yes } \\
\text { Intention }\end{array}$} & $\begin{array}{c}(1) \\
\text { No }\end{array}$ & 11 & 29 & 75 \\
& $(0)$ & 17 & 113 & 14 \\
\hline
\end{tabular}

With the exception of the test between brand awareness and price premium for Thai Airways, all other Chi-square test results are significant. Cramer's V is also calculated for these tests. Per Akoglu (2018), Cramer's V between 0.15 and 0.25 means the association between two variables is strong, and Cramer's V above 0.25 is considered to be very strong. Refer to Table 7 for Chisquare test results and Cramer's V. It is worth mentioning that due to skewed distribution of age, income and travel frequencies of this sample, comparisons between different sub-groups could not produce meaningful results. Results of these comparisons are not reported here.

According to Cohen (1988), when $\mathrm{df}=1$ and effect size is at least 0.30 , the minimum sample size required is 198 to support a strong power of test being as 0.95 . The effective sample size used by this study is 259 , which means the current sample size is large enough for the purpose of the study. 
Table 7

Summary of Chi-Square Test Results and Cramer's V

\begin{tabular}{ccccccc}
\hline \multirow{2}{*}{ Airline } & \multicolumn{2}{c}{$\begin{array}{c}\text { Brand Awareness \& } \\
\text { Purchase Intention }\end{array}$} & \multicolumn{2}{c}{$\begin{array}{c}\text { Brand Awareness \& } \\
\text { Price Premium }\end{array}$} & \multicolumn{2}{c}{$\begin{array}{c}\text { Purchase Intention \& } \\
\text { Price Premium }\end{array}$} \\
\cline { 2 - 7 } & P-value & Cramer's V & P-value & $\begin{array}{c}\text { Cramer's } \\
\text { V }\end{array}$ & P-value & Cramer's V \\
\hline BA & $<0.001$ & 0.402 & $<0.001$ & 0.367 & $<0.001$ & 0.610 \\
CX & $<0.001$ & 0.278 & $<0.001$ & 0.343 & & \\
EK & $<0.001$ & 0.568 & $<0.001$ & 0.489 & $<0.001$ & 0.672 \\
EY & $<0.001$ & 0.422 & $<0.001$ & 0.473 & & \\
MH & $<0.001$ & 0.217 & & & & \\
QF & $<0.001$ & 0.492 & $<0.001$ & 0.465 & $<0.001$ & 0.592 \\
QR & $<0.001$ & 0.391 & $<0.001$ & 0.368 & & \\
SQ & $<0.001$ & 0.548 & $<0.001$ & 0.354 & 0.041 & 0.157 \\
TG & $<0.001$ & 0.426 & $0.072 *$ & 0.142 & 0.009 & 0.190 \\
\hline
\end{tabular}

Note: $\alpha=0.05$ is used for all the tests above as the level of significance.

* The only test that is not significant is between brand awareness and price premium for Thai Airways.

\section{Discussion}

This study inevitably has its limitations. Due to the location and timing of data collection, the sample used by this study is skewed to the younger end of the age spectrum. Considering their travel frequency in the previous 12 months, the sample is mostly composed of leisure travelers. Therefore, results of this study may only represent part of, rather than the entire, population of Australia. In addition, as any other survey-based research, this study cannot ensure all participants have provided honest answers to the survey questions, even the research team has given their best effort to verbally communicate with every participant to explain research objectives and to double check the accuracy of responses provided.

The approach to data collection could potentially contribute to the significance found by this study. Rather than asking participants directly if they have heard of a certain airline to measure brand awareness, researchers ask participants to name airline logos they could recognize. Recognition is a stronger form of awareness in that it indicates not only knowledge of existence but also familiarity. Meanwhile, for purchase intention and price premium, a verbal confirmation in a survey does not always suggest the actual commitment in real world. Audience should note this when interpreting findings of this study.

Singapore Airlines is an interesting case. For years, both media and the public by default group Singapore Airlines into the premium full-service carrier 
category. To many frequent travelers, they are the benchmark of service and quality in the airline industry. In this study, even Singapore still remains as one of the most recognizable airline brands in an oversea market (Australia) and quite a lot of participants indicate their intentions of flying with Singapore, the unexpected number of participants who put Singapore into the discount category definingly warrants a scrutiny. A follow-up study could potentially identify extremely valuable insights to improve the brand image of Singapore Airlines in the Australia market.

Airlines understand the importance of marketing. Leading international carriers such as Emirates (2018) are spending hundreds of millions of dollars per annum to sponsor sports, cultural and arts events to promote their brand and products. Full-service carriers are also investing on providing the most exclusive and lavish cabin products to maintain their attraction to premium travelers and to strengthen their brand positioning in the tourism market (Dirsehan \& Kurtuluş, 2018). Airlines are investing on social media marketing activities to promote brand awareness (Seo \& Park, 2018). Such an effort and expense are being paid off. The Emirates brand is widely recognized in the global market, and such brand awareness is positively contributing to passengers' purchase intention as well as price premium.

Findings of this study are pointing a direction for future studies. Systematic random sampling should be used to select a sample that better represents the Australia market. In addition to investigating the correlation, a qualitative study using focus groups or interview could potentially provide more insights to reveal the logic behind these correlations. Airlines, with their direct access to sales data, should analyze the link between brand awareness changes and sales growth/decline to identify possible causation.

\section{Conclusions}

Demographic information suggests that the majority of participants fit the profile of leisure travelers, considering the majority of survey participants are young, have lower income and don't travel frequently in a year (Table 2). Leisure travelers typically are sensitive to price, mostly fly economy class, and book tickets in advance in order to save. However, airfare is not the only factor leisure travelers will consider when choosing between different airlines. Their impressions with a particular airline are also from a more holistic perspective. In particular, prior experience and familiarity with the airline play important roles in their decision making (Gao \& Koo, 2014).

In terms of brand awareness among survey participants, the most recognized airline brands are Qantas Airways (74.1\%), Singapore Airlines (61\%), Thai Airways (58.7\%), and Emirates (49.8\%). This awareness standing is very similar to the current market share of international airlines in the Australia market 
(see Figure 4). The exception is Thai Airways, whose market share is less than $3 \%$ but ranks $3^{\text {rd }}$ in terms of awareness among all airlines in this study.

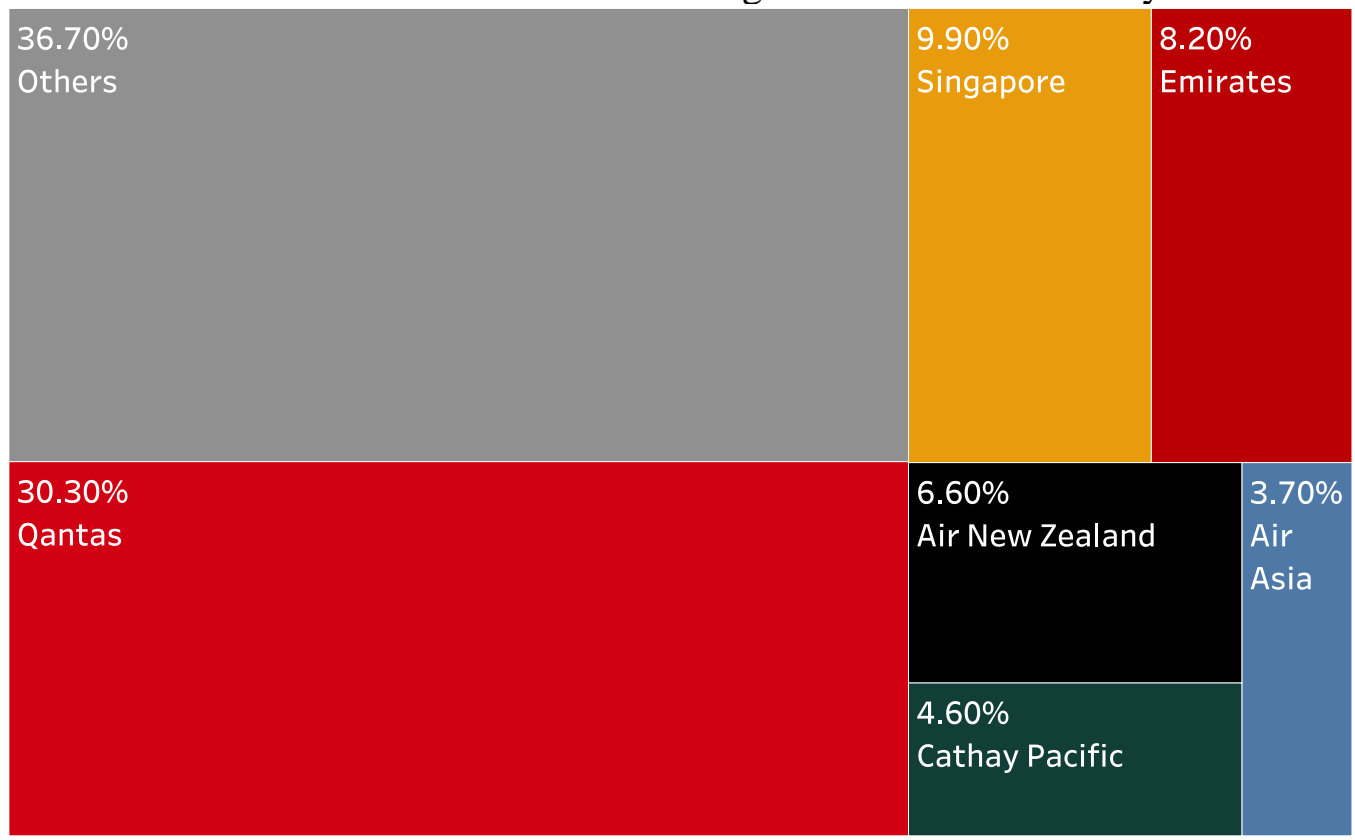

Figure 4. Market share of international airlines in Australia (international routes). Adapted from "International Airlines in Australia" by T. Youl, 2018, IBISWorld Industry Report I4901.

Responses to the purchase intention question also match the market share standing well. More participants would select Qantas, Singapore, and Emirates over other airlines when travelling between Australia and the UK, and these are also the top 3 airlines in terms of market share on the international market to or from Australia. Such a match can be viewed as a testimony for the quality of responses collected by this study.

Price premium is one of the most useful dimensions in measuring brand equity (Aaker, 1996; Blackston, 1995; Sethuraman, 2001). In Australia's international airline market, Qantas and Emirates are clearly viewed by many as premium brands. Such an association will place both airlines on a strong position to charge premium airfares. What's interesting is Singapore Airlines. A higher than expected percentage of participants don't agree with the conventional reputation of the airline, and group them into the discount choice group. This is calling for the attention of Singapore Airlines, who traditionally view Australia as one of its most important oversea markets. Another intriguing finding is Thai Airways. As one of the top three most recognized airline brands in this study, the skewed survey responses reveal that Australian customers recognize its brand as a 
discount airline. This strong identification could seriously affect airlines' sales and revenue, calling the airline for a thorough study of its brand image in Australia.

For airlines that meet the Chi-square test assumption requirements, significant correlation between brand awareness and purchase intention are found, suggesting the positive effect of brand equity on purchase intention. Measured by Cramer's V, the correlations are quite strong. This is confirmatory to the finding of Chen and Chang (2008) that brand equity has positive effect on both brand preference and purchase intention. Similarly, significance is found between brand awareness and price premium, and between purchase intention and price premium. All of above results are justifying airlines' expenditures on brand promotions in the Australia market. 


\section{References}

Aaker, D. (1996). Measuring brand equity across products and markets. California Management Review, 38(3), 102. doi:10.2307/41165845

Airline Deregulation Act. (1978). PUB. L. No. 95-504, 92 Stat. 1705. Akoglu, H. (2018). User's guide to correlation coefficients. Turkish Journal of Emergency Medicine, 18(3), 91-93. doi:10.1016/j.tjem.2018.08.001

Anselmsson, J., Johansson, U., \& Persson, N. (2007). Understanding price premium for grocery products: A conceptual model of customer-based brand equity. Journal of Product \& Brand Management, 16(6), 401-414. doi:10.1108/10610420710823762

Anselmsson, J., Vestman Bondesson, N., \& Johansson, U. (2014). Brand image and customers' willingness to pay a price premium for food brands. Journal of Product \& Brand Management, 23(2), 90-102. doi:10.1108/JPBM-10-2013-0414

Berry, L. (2000). Cultivating service brand equity. Official Publication of the Academy of Marketing Science, 28(1), 128-137. doi:10.1177/0092070300281012

Blackston, M. (1995). The qualitative dimension of brand equity. (Research International, Brand and Communication President Max Blackston speech)(Research Currents)(Transcript). Journal of Advertising Research, 35(4), RC2.

Brey, R., \& Walker, J. L. (2011). Latent temporal preferences: An application to airline travel. Transportation Reserach Part A, 45(9), 849-992. doi:10.1016/j.tra.2011.04.010

Bureau of Transport Economics. (1995). Deregulation of domestic aviation in Australia 1990-1995. Retrieved from https://bitre.gov.au/publications/ 1995/files/is_006.pdf

Chen, C.-F., \& Chang, Y.-Y. (2008). Airline brand equity, brand preference, and purchase intentions-The moderating effects of switching costs. Journal of Air Transport Management, 14(1), 40-42. doi:10.1016/j.jairtraman.2007.11.003

Chen, C.-F., \& Tseng, W.-S. (2010). Exploring customer-based airline brand equity: Evidence from Taiwan. Transportation Journal, 49(1), 24-34.

Cohen, J. (1988). Statistical power analysis for the behavioral sciences (2nd ed.). Hillsdale, N.J.: L. Erlbaum Associates.

Dirsehan, T., \& Kurtuluş, S. (2018). Measuring brand image using a cognitive approach: Representing brands as a network in the Turkish airline industry. Journal of Air Transport Management, 67, 85-93. doi:10.1016/j.jairtraman.2017.11.010 
Emirates. (2018). The Emirates Group annual report 2017-2018. Retrieved from https://cdn.ek.aero/downloads/ek/pdfs/report/annual_report_2018.pdf

Gao, Y., \& Koo, T. T. R. (2014). Flying Australia-Europe via China: A qualitative analysis of the factors affecting travelers' choice of Chinese carriers using online comments data. Journal of Air Transport Management, 39, 23-29. doi:10.1016/j.jairtraman.2014.03.006

Gómez, M., Martín-Consuegra, D., Díaz, E., \& Molina, A. (2018). Determinants and outcomes of price premium and loyalty: A food case study. Journal of Consumer Behaviour, 17(1), 64-74. doi:10.1002/cb.1692

Jeng, S. P. (2016). The influences of airline brand credibility on consumer purchase intentions. Journal of Air Transport Management, 55, 1-8. doi:10.1016/j.jairtraman.2016.04.005

Keller, K. L., \& Lehmann, D. R. (2003). How do brands create value? Marketing Management, 12(3), 26-31.

Macias, W. \& Rodriquez, K. (2018). Brand valuation by price premium: Theoretical explanation and practical application using conjoint analysis. Knowledge Management: An International Journal, 17, 13-27. doi:10.18848/2327-7998/CGP/v17i03/13-27

Masuda, K., \& Kushiro, S. (2018). Influence of brand equity on the price premium for private labels in fresh produce: A contingent valuation survey. Agribusiness, 34(2), 338-350. doi:10.1002/agr.21498

McHugh, M. L. (2013). The chi-square test of independence. Biochemia Medica, 23(2), 143-149. doi:10.11613/BM.2013.018

Moreno, M. B. (2006). Airline choice for domestic flights in São Paulo metropolitan area: An application of the conditional logit model. Journal of Air Transportation, 11(2), 22-42.

Persson, N. (2010). An exploratory investigation of the elements of B2B brand image and its relationship to price premium. Industrial Marketing Management, 39(8), 1269-1277. doi:10.1016/j.indmarman.2010.02.024

Sarker, M. M., Mohd-Any, A. A., \& Kamarulzaman, Y. (2019). Conceptualising consumer-based service brand equity (CBSBE) and direct service experience in the airline sector. Journal of Hospitality and Tourism Management, 38, 39-48. doi:10.1016/j.jhtm.2018.11.002

Seo, E.-J., \& Park, J.-W. (2018). A study on the effects of social media marketing activities on brand equity and customer response in the airline industry. Journal of Air Transport Management, 66, 36-41. doi:10.1016/j.jairtraman.2017.09.014

Sethuraman, R. (2001). What makes consumers pay more for national brands than for store brands - image or quality? Review of Marketing Science, WP No. 318. Retreived from https://papers.ssrn.com/sol3/ papers.cfm? abstract_id=310883 
Suchomelova, A., Prochazka, J., \& Durinik, M. (2017). Personal interest branding: Source of price premium. Journal of International Consumer Marketing, 29(1), 27-34. doi:10.1080/08961530.2016.1236309

Thakshak. (2018). Analysing customer based airline brand equity: Perspective from Taiwan. Future Business Journal, 4(2), 233-245. doi:10.1016/j.fbj.2018.07.001

U.S. Department of State. (n.d.).Civil air transport agreements. Retrieved from https://www.state.gov/e/eb/tra/ata/

Yai, T., Takada, K., \& Okamoto, N. (1997). Analysis of international air passenger characteristics in the Asian region. https://doi.org/10.1016/j.ajsl.2017.09.002

Youl, T. (2018). International airlines in Australia. IBISWorld Industry Report 14901. Retreived from https://www.ibisworld.com.au/industrytrends/market-research-reports/transport-postal-warehousing/airspace/international-airlines.html 